\title{
Formulation Design of the Oral Disintegrating Tablets Including Alfuzosin Hydrochloride with Risk Evaluation via Quality by Design
}

\author{
Gözde Güncan', Gizem Yeğen², Burcu Mesut', Buket Aksu², Yıldız Özsoy \\ ${ }^{1}$ Department of Pharmaceutical Technology, Faculty of Pharmacy, Istanbul University, 34116, Istanbul, Turkey. \\ ${ }^{2}$ Department of Pharmaceutical Technology, Faculty of Pharmacy, Istanbul Kemerburgaz University, 34145, Istanbul, Turkey.
}

\begin{abstract}
In this study, within the framework of Quality by Design which is a systematically scientific approach which enables to understand and control the production and formulation variables during the process design and development, different parameters in the formulation and production process were detected and critical process parameters and critical material attributes were determined via risk evaluation methods. Then, different oral disintegrating tablet formulations were prepared and tested by changing the usage of co-formulated disintegrating excipient and other disintegrant combined with sodium starch glycolate and mannitol. Powder flow characteristics were examined. Suitable formulations compressed via direct compression method at two different pressure levels. Compressed tablets were tested physically and chemically. The results thus obtained were evaluated in the Artificial Neural Network and Gene Expression Programming modules.
\end{abstract}

Keywords: Oral Disintegrating Tablets, Alfuzosin Hydrochloride, Quality by Design, Artificial Neural Network, Gene Expression Programming

\section{INTRODUCTION}

Today, it is generally accepted that quality cannot be tested or inspected into a finished product, but rather that quality, safety and effectiveness must be "designed" and built into a product and its manufacturing process. In the traditional approach, the production processes and process parameters are determined to be unchanged in order to avoid any variety in the quality of the product. Thus, required specifications are met and the product quality is measured by finished product tests ${ }^{1}$. In order to design quality into a product, the requirements for the product design and performance must be well understood in the early design phase. In pharmaceuticals, these product requirements can be justified as Quality Target Product Profile (QTPP) which is also defined as "a prospective summary of

${ }^{*}$ Corresponding author: Yıldız Özsoy

E-mail: yozsoy@istanbul.edu.tr 
the quality characteristics of a drug product that ideally will be achieved to ensure the desired quality, taking into account safety and efficacy of the drug product" 2

On the other hand, Quality by Design (QbD) method identifies characteristics that are critical to quality from the perspective of patients, translates them into attributes that the drug product should possess, and establishes how the process factors can be varied to consistently produce a drug product with the desired characteristics. The QbD approach begins with a predefined target product profile (TPP), and applies various principles and tools at different stages to better understand the product. Quality risk assessment (QRA) tools, such as Failure Mode Effects Analysis (FMEA) and Risk ranking and filtering, is applied to identify an initial list of potential Critical Quality Attributes (CQAs), Critical material attributes (CMAs) and Critical Process Parameters (CPPs) with risk assessment for each unit operation includes considering and documenting all parameters that could affect outputs (CQAs) ${ }^{3-4}$.

CQAs mainly refer to quality attributes of raw material, intermediate or final product $^{5}$. CQAs are those physical, chemical, biological or microbiological property or characteristic that should be within an appropriate limit, range or distribution to ensure the desired product quality. CQA assessment is an iterative process of evaluating the drug product and drug substance attributes throughout development to determine which have potential impact on the safety, efficacy, or potency of the drug 6

The process and product design applied by QbD approach decrease the role of finished product tests and so ensure to be able to control quality at the design stage. When compared with traditional development approaches, formulation and manufacturing process dynamics are better understood in QbD approach. Moreover, the formulation contributes understanding the effect of production processes on product reliability and efficacy ${ }^{7}$.

Design of Experiments (DoE) is a part of QbD and defined as a structured and organized method to determine the relationship among factors that influence outputs of a process. DoE results can help identify optimal conditions, the critical factors that most influence CQAs. Based on the acceptable range of CQAs, the design space of CPPs can be determined ${ }^{8}$.

In ICH Q89, Design Space is defined as "the multidimensional combination and interaction of input variables (e.g., material attributes) and process parameters that have been demonstrated to provide assurance of quality"8. Working within this space is not considered as a change and hence does not require regulatory approval.

The latest advances in mathematics and computer science have developed methods that may aid complex data analysis throughout DoE, optimisation with mod- 
elling and creating design space, and thus, different software products based on mathematical models have been developed to help to better understand the relationship between formulation and process parameters, ensures quality of product and to save time and money ${ }^{10}$. There are many computer software's employing Artificial Neural Network (ANN), Gene Expression Programming (GEP) and Neuro-Fuzzy Logic Modelling infrastructure for this purpose serving the pharmaceutical industry ${ }^{11}$. One of these software's is INForm of Intelligensys Ltd., UK that employs multilayer perceptron neural networks.

Artificial neural networks are calculation models inspired by biology that consist of hundreds of units and artificial neurons connected by factors (weights) that establish the neural network without any linear relationship. Nonetheless, the most important factor in deciding to use neural networks to solve a problem concerns whether the data represent the solution of the problem ${ }^{10}$.

On the other hand, GEP is a transactional process producing best fitting integral solutions based on the principle of the most powerful survives (natural selection) in the complicated and multidimensional research fields and by mapping complex neural networks of different shapes and sizes (phenotype) in this process, they use linear chromosomes (genotype) ${ }^{12}$.

Orally Disintegrating Tablet (ODT) is a solid unit dosage form, which disintegrates or dissolves rapidly in the mouth without chewing and water. This type of property in dosage form can be attained by addition of different excipients, from which disintegrating excipient is the key adjuvant ${ }^{13}$. ODTs are appreciated by a significant segment of populations particularly who have difficulty in swallowing. It has been reported that Dysphagia (difficulty in swallowing) is common among all age groups and more specific with paediatric, geriatric population along with psychiatric patients and patients with nausea, vomiting, and motion sickness complications ${ }^{14}$.

Formulation properties and process parameters affect the disintegration time of ODTs. In this kind of tablets, direct compression is the most common used technique that requires the integration of disintegrants into the formulation to achieve the fast disintegration of tablets. To decrease the disintegration time of the tablet, it is necessary to avoid increasing the mechanical strength of ODTs. The mechanical strength of a tablet is related to its compression pressure and friability is inversely related to compression pressure. To ensure the quality of an ODT, these two properties should be properly balanced. ODTs can be soft, fragile so unsuitable for packaging in conventional blisters or bottles because of their low compression pressure, it is therefore necessary to develop a strategy to increase the tablet's mechanical strength without sacrificing its porosity or requiring special unit dose packaging, which may add to the cost of handling fragile tablets ${ }^{15}$.

Alfuzosin hydrochloride is an alpha-adrenoreceptor blocker used in the manage- 
ment of hypertension and it also relieves symptoms of urinary obstructions in benign prostatic hyperplasia ${ }^{16}$. The concept of formulating orally disintegrating tablets containing alfuzosin offers a suitable and practical approach in serving desired objective of rapid disintegration and dissolution characteristics with increased bioavailability ${ }^{17}$. In this study, alfuzosin hydrochloride was chosen as the model medication because of its low-dosage active ingredient and its indication.

In our study, different formulations were tested by changing the ready to use coformulated disintegrant excipient (Ludiflash or combined sodium starch glycolate and mannitol), disintegrant \% rate (30-80 \%) and tablet compression pressure (500 or 1000 psi). Thereafter, the relationships between the formulation and process parameters and the target product properties (tablet hardness, friability, wetting time, water absorption ratio and disintegration time) and the pharmaceutically acceptable ODT formulation were determined using ANN and GEP models.

\section{METHODOLOGY}

\section{Materials}

Alfuzosin hydrochloride was obtained from Generica Drug Company (Turkey) as a gift. Avicel PH 101 (microcrystalline cellulose NF) was from FMC Biopolymer (Brussels, Belgium), and Ludiflash $®$ was from BASF (Germany), Sodium stearyl fumarate was from SPI Pharma (U.S.A.), sodium starch glycolate was from DFE Pharma (Germany) and Mannitol was from Merck Co. (Germany). All other solvents and chemicals used were of analytical grade.

\section{Methods}

\section{Creating Knowledge Space}

First step of QbD framework starts with definition of CQA and application QbD by unit operation, working backwards from Drug Product after definition of QTPP. Subsequently, it continues with risk assessment on each unit operation and conduct designed experiments.

\section{Quality Target Product Profile (QTPP)}

The QTPP is derived from the desired labelling information that describes anticipated indications, contraindications, dosage form, dose, frequency, pharmacokinetics, and so on, for a new product ${ }^{18}$. There are various ways to represent a QTPP for ODT and one of them was given in Table 1.

\section{Identify CQAs}

CQAs are derived from QTPP and scientific rationale for CQAs should be explained. Table 2 summarizes the quality attributes of ODTs and indicates which attributes were classified as drug product CQAs. 
Table 1: Quality Target Product Profile (QTPP) for ODT.

\begin{tabular}{|c|c|c|}
\hline \multicolumn{3}{|c|}{ Quality Target Product Profile (QTPP) for ODT } \\
\hline QTPP Element & Target & Justification \\
\hline Dosage form & ODT & Patient compliance \\
\hline Route of administration & Oral & Patient compliance \\
\hline Dosage strength & $2,5 \mathrm{mg}$ & Maximum effect \\
\hline & Physical Attributes (hardness, friability) & \multirow{7}{*}{$\begin{array}{l}\text { Pharmaceutical limit } \\
\text { requirement }\end{array}$} \\
\hline & Disintegration time & \\
\hline & Wetting time & \\
\hline & Water Content & \\
\hline & Content Uniformity & \\
\hline & Drug Release & \\
\hline & Microbial Limits & \\
\hline
\end{tabular}

Table 2: Critical Quality Attributes (CQAs) of ODTs.

\begin{tabular}{|c|c|c|c|}
\hline \multicolumn{4}{|c|}{ Critical Quality Attributes (CQAs) of ODTs } \\
\hline $\begin{array}{c}\text { Quality } \\
\text { Attributes of the } \\
\text { Drug Product } \\
\end{array}$ & Target & $\begin{array}{l}\text { Is it a } \\
\text { CQA? }\end{array}$ & Justification \\
\hline Appearance & $\begin{array}{l}\text { Colour and shape } \\
\text { acceptable to the } \\
\text { patient. No visual } \\
\text { tablet defects } \\
\text { observed. }\end{array}$ & No & $\begin{array}{l}\text { Colour, shape and appearance are not directly } \\
\text { affect safety and efficacy. Therefore, they } \\
\text { are not critical. . The target is set to ensure } \\
\text { patient acceptability. }\end{array}$ \\
\hline Size & $\begin{array}{c}<20 \mathrm{mg} \text { (amount of } \\
\text { active ingredient) }\end{array}$ & Yes & $\begin{array}{l}\text { Size is critical as it affects wetting time and } \\
\text { disintegration }\end{array}$ \\
\hline Odour, taste & $\begin{array}{c}\text { No unpleasant odour } \\
\text { and taste }\end{array}$ & Yes & $\begin{array}{l}\text { Odour and taste are critical in ODTs owing } \\
\text { to patient convenience }\end{array}$ \\
\hline Friability & $<\% 1$ & Yes & High friability causes decrease in size \\
\hline Hardness & $\begin{array}{l}\text { Pharmacopeia } \\
\text { acceptability }\end{array}$ & Yes & $\begin{array}{l}\text { Hardness affect disintegration time } \\
\text { and drug efficiency }\end{array}$ \\
\hline $\begin{array}{l}\text { Disintegration } \\
\text { time }\end{array}$ & $<3$ minutes & Yes & Disintegration time affects efficiency \\
\hline Wetting time & Minimum & Yes & Wetting time affect disintegration time \\
\hline $\begin{array}{l}\text { Water absorption } \\
\text { capacity }\end{array}$ & Minimum & Yes & $\begin{array}{l}\text { When the water absorption capacity is } \\
\text { high more saliva is required to } \\
\text { disintegrating ODT in mouth }\end{array}$ \\
\hline Drug release & $\begin{array}{l}\text { Pharmacopeia } \\
\text { acceptability }\end{array}$ & Yes & $\begin{array}{l}\text { Drug release affects drug efficiency } \\
\text { and safety }\end{array}$ \\
\hline $\begin{array}{l}\text { Content } \\
\text { Uniformity }\end{array}$ & $\begin{array}{l}\text { Pharmacopeia } \\
\text { acceptability }\end{array}$ & Yes & $\begin{array}{l}\text { Variability in content uniformity will } \\
\text { affect safety and efficiency. Content } \\
\text { uniformity of ODTs is critical. }\end{array}$ \\
\hline
\end{tabular}


An overall risk assessment of the drug product formulation components was performed to determine which formulation components have a high risk of impacting the drug product CQAs. Table 3 shows us risk assessment results for formulation component effect on powder blend as a sample.

Table 3: Risk assessment of the formulation components.

\begin{tabular}{|c|c|}
\hline \multirow{2}{*}{ Drug Product CQAs } & Formulation Components \\
\cline { 2 - 2 } & Powder Blend \\
\hline Size & No \\
\hline Taste, odour & Low \\
\hline Friability & High \\
\hline Hardness & High \\
\hline Disintegration time & Medium \\
\hline Wetting time & Medium \\
\hline Water absorption capacity & Medium \\
\hline Drug release & High \\
\hline Content uniformity & High \\
\hline
\end{tabular}

Since the detailed production processes were not set up during the risk assessment stage of the formulation development, risk analysis has been carried out on each and every formulation characteristic to achieve the optimized production process. Formulation variables of the powder mixture have been determined and effects of these variables on the critical quality parameters have been determined by the risk assessment (Table 4).

Table 4: Risk assessment of formulation variables.

\begin{tabular}{|c|c|c|c|c|c|}
\hline \multirow{2}{*}{$\begin{array}{c}\text { Powder blend } \\
\text { CQAs }\end{array}$} & \multicolumn{5}{|c|}{ Formulation Variables } \\
\cline { 2 - 6 } & $\begin{array}{c}\text { Dispersant } \\
\text { Type }\end{array}$ & $\begin{array}{c}\text { Dispersant } \\
\text { Amount }\end{array}$ & $\begin{array}{c}\text { Lubricant } \\
\text { Amount }\end{array}$ & $\begin{array}{c}\text { Sweetening } \\
\text { Agent }\end{array}$ & $\begin{array}{c}\text { Particle } \\
\text { size }\end{array}$ \\
\hline Taste & Medium & Medium & Medium & High & Low \\
\hline Bulk Density & Low & Low & Low & Low & High \\
\hline Tapped Density & Low & Low & High & Low & High \\
\hline Hausner ratio & High & High & Medium & Medium & High \\
\hline Carr's Index & High & High & High & Medium & High \\
\hline
\end{tabular}




\section{Applying QbD by Unit Operation}

The purpose of each unit operation should guide evaluation of critical attributes (CQAs) with defining unit operations by specific output required and considering the order of unit operations. Figure 1 shows the unit operation steps, quality attributes of input and output materials and also all process parameters for all steps.

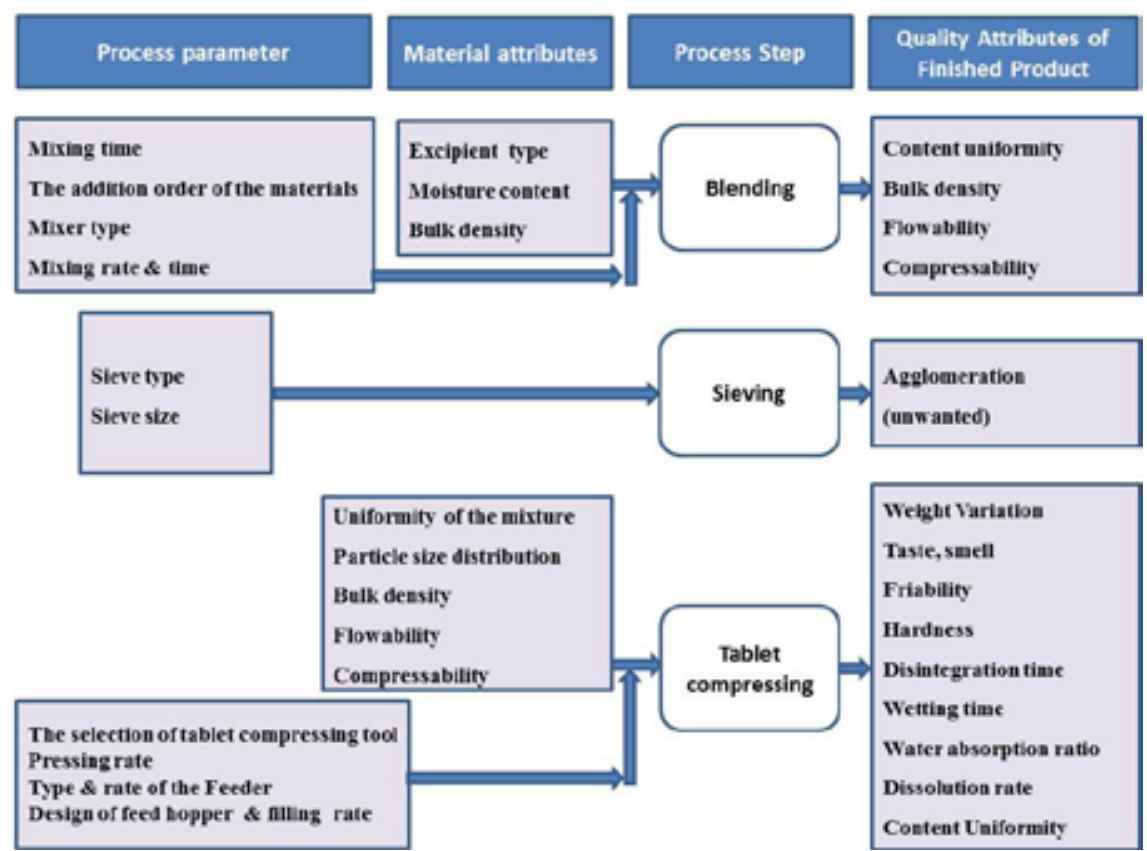

Figure 1: Unit operations map.

\section{Risk Assessment}

FMEA (failure modes and effects analysis) or use of a prioritization matrix (cause and effect matrix) is helpful in identifying the process inputs that impact on quality attributes. In some cases, a deeper dive into the driving forces at critical control points in the manufacturing process can yield a more fundamental understanding of sources of variation ${ }^{18}$. A risk assessment was performed and ten process parameters were evaluated using FMEA as a risk assessment tool to quantify the degree of risk associated with these materials and the design and process variables. As a part of the assessment, a system of ranking named risk qualification was established. The three rankings were severity (S), probability (P) and detectability (D) and are shown in Table 5. Severity (S) assesses the implications of a failure and how this failure may affect the quality of a product. The possibility of a failure is called the probability of occurrence, whereas detectability is the capability to detect failure modes. The S, P and D scores are multiplied to calculate a risk priority number (RPN) to list each risk according to its rank. Each score is given an 
assessment point from one to five, and the multiplied RPN scores are classified as follows: Low (1-45), Moderate (46-90) and High (91-125). For a high RPN, the potential risks were deemed to have a critical adverse effect on the product quality ${ }^{19}$.

Table 5: Ranking of severity (S), probability (P) and detectability (D).

\begin{tabular}{|c|c|c|}
\hline \multicolumn{3}{|r|}{ SEVERITY } \\
\hline Score & Definition & Description \\
\hline 1 & Very low & $\begin{array}{l}\text { Predicted to have no impact on product quality } \\
\text { (quality within specifications). }\end{array}$ \\
\hline 2 & Low & $\begin{array}{l}\text { Predicted to have a minor impact on product quality } \\
\text { (failure to meet specifications). }\end{array}$ \\
\hline 3 & Moderate & $\begin{array}{l}\text { Predicted to have a noticeable impact on product quality, } \\
\text { but can be recovered. }\end{array}$ \\
\hline 4 & High & $\begin{array}{l}\text { Predicted to have a definite impact on product quality that } \\
\text { may require rework. }\end{array}$ \\
\hline 5 & Extreme & $\begin{array}{l}\text { Predicted to have a severe impact on product quality and } \\
\text { cause batch failure that is not recoverable. }\end{array}$ \\
\hline \multicolumn{3}{|r|}{ OCCURRENCE } \\
\hline Score & Definition & Description \\
\hline 1 & Unlikely & $\begin{array}{l}\text { Failure is unlikely to occur. Failure has never been seen } \\
\text { but it is theoretically possible. }\end{array}$ \\
\hline 2 & Rare & $\begin{array}{l}\text { Failure is rare but has a remote probability. } \\
\text { Failure has been seen once or twice. }\end{array}$ \\
\hline 3 & Occasional & $\begin{array}{l}\text { Failure infrequently occurs. Failure has been observed in } \\
\text { several experiments. }\end{array}$ \\
\hline 4 & $\begin{array}{l}\text { Moderate / } \\
\text { Probable }\end{array}$ & $\begin{array}{l}\text { Failure potential is low. Failure has been observed in several } \\
\text { experiments and may require in-process controls. }\end{array}$ \\
\hline 5 & $\begin{array}{l}\text { High/ } \\
\text { Frequent }\end{array}$ & Failure is expected to occur regularly. Failure potential is high. \\
\hline \multicolumn{3}{|r|}{ DETECTABILITY } \\
\hline Score & Definition & Description \\
\hline 1 & Always & Failure can be detected in all cases. Failure is clearly visible. \\
\hline 2 & Regular & Failure can be detected almost every time. \\
\hline 3 & Likely & $\begin{array}{l}\text { Failure cannot be detected occasionally. } \\
\text { Failure may be missed sometimes. }\end{array}$ \\
\hline 4 & Low & Failure is probably not detected. Failure may be missed often. \\
\hline 5 & $\begin{array}{l}\text { Very low/ } \\
\text { no detection }\end{array}$ & $\begin{array}{l}\text { Failure cannot be detected/Failure cannot be detected } \\
\text { with the available equipment or method. }\end{array}$ \\
\hline
\end{tabular}


Table 6 shows the risk score matrix, which is a part of FMEA.

Table 6: Risk assessment with FMEA.

\begin{tabular}{|c|c|c|c|c|c|c|c|c|c|c|}
\hline & 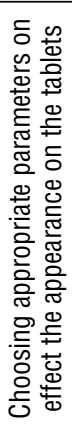 & 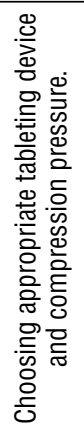 & 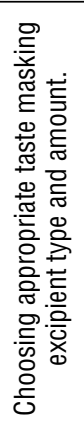 & 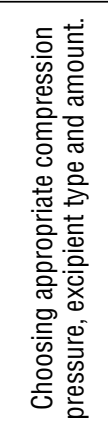 & 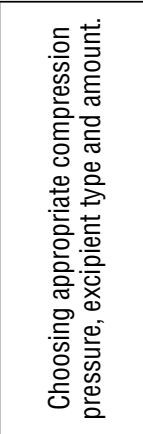 & 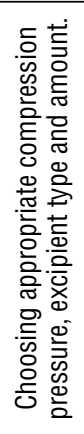 & 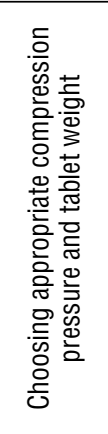 & 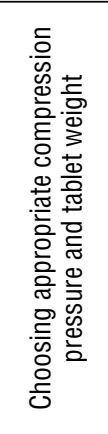 & 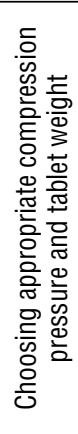 & 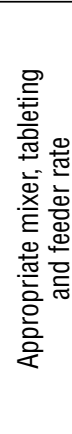 \\
\hline$\frac{z_{\frac{1}{\alpha}}^{*}}{z^{2}}$ & 요 & $\stackrel{\infty}{\sim}$ & 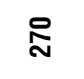 & প্র & 守 & ఫ్లి & 守 & 읏 & ర్రి & ర్రి \\
\hline מ* & مما & os & o & 으 & 으 & 으 & 으 & 으 & 으 & 으 \\
\hline * & 0 & m & m & $\nabla$ & m & m & m & m & 0 & 0 \\
\hline * & m & $\infty$ & 으 & 으 & $\infty$ & 으 & $\infty$ & 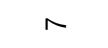 & 으 & 으 \\
\hline 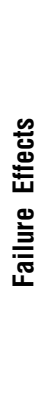 & 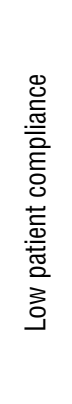 & 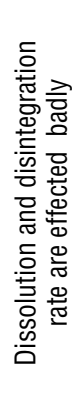 & 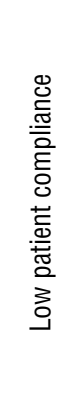 & 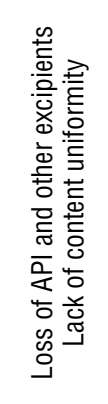 & 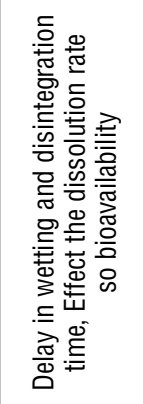 & 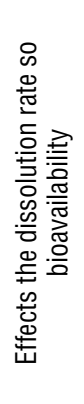 & 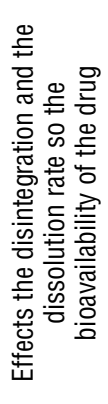 & 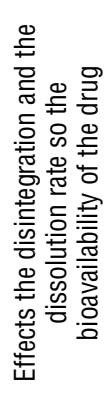 & 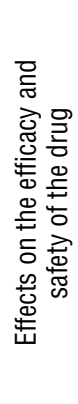 & 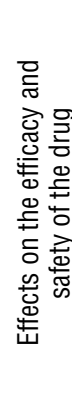 \\
\hline 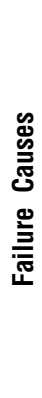 & 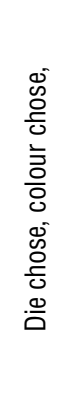 & 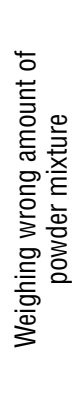 & 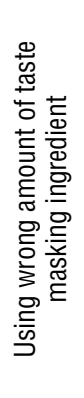 & 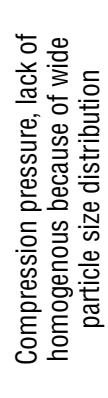 & 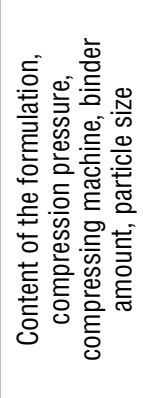 & 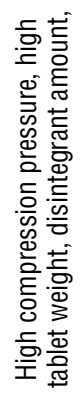 & 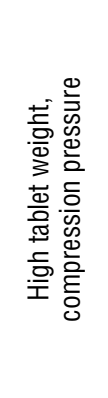 & 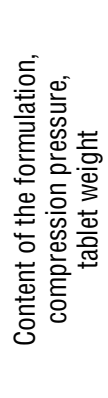 & 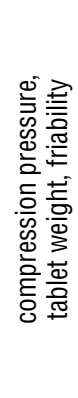 & 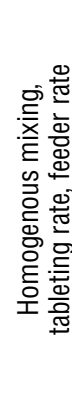 \\
\hline 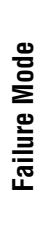 & 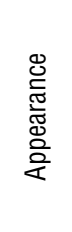 & 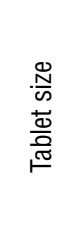 & 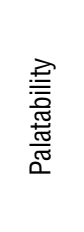 & 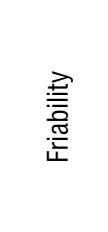 & 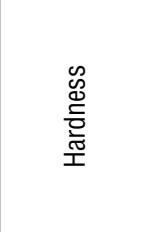 & 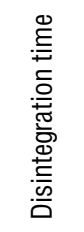 & 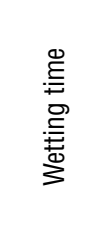 & 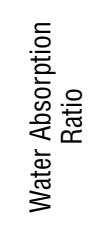 & 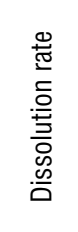 & 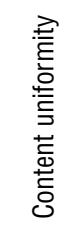 \\
\hline
\end{tabular}

${ }^{*}$ S: Severity, P: Probability, D: Detectability and RPN: Risk priority number 
The potential CQAs of excipients required for development of ODTs were identified to have minimum disintegration time, water absorption capacity and wetting time with maximum hardness at friability not greater than $1 \%$, also sweat taste for patient convenience.

In this study, CMAs (disintegrant type and amount) and CPPs (tablet compression pressure) were considered the inputs, and QTPP properties (hardness, friability, wetting time, water absorption ratio and disintegration time) were the outputs.

\section{Evaluation of the Granulations and ODT Tablets}

Alfuzosin hydrochloride granulations were prepared according to the following independent variables: disintegrant type (Ludiflash $®$ or combination of mannitol and sodium starch glycolate (SSG)), disintegrant excipient \% rate (30-80\%) and tablets were pressed at pressures 500 or $1000 \mathrm{psi}$ ). The formulation variables and tablet compression pressures used are given in Table 7.

Table 7: Composition and compression pressure of ODT formulations.

\begin{tabular}{|c|c|c|c|c|c|c|}
\hline \multirow{2}{*}{ Variable } & \multicolumn{6}{|c|}{ Formulation } \\
\hline & F1 & F2 & F3 & F4 & F5 & F6 \\
\hline Compressive strength & 500 & 500 & 500 & 1000 & 1000 & 1000 \\
\hline Alfuzosin $\mathrm{HCl}(\mathrm{mg})$ & 2,5 & 2,5 & 2,5 & 2,5 & 2,5 & 2,5 \\
\hline Ludiflash® (mg) & 60 & 120 & 160 & 60 & 120 & 160 \\
\hline Avicel $^{\circledR}(\mathrm{mg})$ & 135,1 & 75,1 & 35,1 & 135,1 & 75,1 & 35,1 \\
\hline $\mathrm{SSF}^{\star}(\mathrm{mg})$ & 2,4 & 2,4 & 2,4 & 2,4 & 2,4 & 2,4 \\
\hline \multirow[t]{2}{*}{ Total weight (mg) } & 200 & 200 & 200 & 200 & 200 & 200 \\
\hline & F7 & F8 & F9 & F10 & F11 & F12 \\
\hline Compressive strength & 500 & 500 & 500 & 1000 & 1000 & 1000 \\
\hline Alfuzosin $\mathrm{HCl}(\mathrm{mg})$ & 2,5 & 2,5 & 2,5 & 2,5 & 2,5 & 2,5 \\
\hline Mannitol+ SSG (mg) & 60 & 120 & 160 & 60 & 120 & 160 \\
\hline Avicel $^{\circledast}(\mathrm{mg})$ & 135,11 & 75,1 & 35,1 & 135,1 & 75,1 & 35,1 \\
\hline $\mathrm{SSF}^{\star}(\mathrm{mg})$ & 2,4 & 2,4 & 2,4 & 2,4 & 2,4 & 2,4 \\
\hline Total weight (mg) & 200 & 200 & 200 & 200 & 200 & 200 \\
\hline
\end{tabular}

${ }^{*}$ Sodium stearyl fumarate

After blending all ingredients, bulk density, tapped density, Carr's index and Hausner ratio tests of prepared granulation formulations were carried out according to Eur. Pharm. ${ }^{20-21}$ requirements. 
The granules were compressed into tablets by using a single tablet punch press machine (Korsch, EK-o, Germany) using two different compression pressures (500 or $1000 \mathrm{psi}$ ). All the formulated ODTs were subjected to the following quality control tests.

\section{Weight Variation}

The weight variation test is carried out in order to ensure uniformity in the weight of tablets. The total weight of 20 tablets from each formulation is determined and the average is calculated. The individual weight of the each tablet is also determined to find out the weight variation.

\section{Tablet Hardness}

The hardness of tablet is an indication of its strength. Measuring the force required to break the tablet across tests it. Tablet hardness was measured, mean value and standard deviation was calculated $(n=10)$.

\section{Friability}

Friability is the loss of weight of tablet in the container due to removal of fine particles from the surface. Tablets were weighed and placed in a standard Erweka $^{\circledR}$ friabilator. The friabilator was operated at $25 \mathrm{rpm}$ for $4 \mathrm{~min}$, and the friability was then calculated as the percent loss in weight after the run ${ }^{22}$.

\section{Wetting Time and Water Absorption Ratio}

For this purpose, a tablet was placed on a piece of tissue paper folded twice and kept in a small Petri dish (ID $=6.5 \mathrm{~cm}$ ) containing $6 \mathrm{ml}$ of water, and the time for complete wetting was measured. The wetted tablet was then reweighed to evaluate water absorption ratio. Water absorption ratio \%, $\mathrm{R}$ was determined according to the literature $\mathrm{e}^{23-24}$.

\section{In Vitro Disintegration Test}

The in vitro disintegration test was performed according to the European Pharmacopoeia at $37 \pm 2^{\circ} \mathrm{C}$ in $900 \mathrm{~mL}$ of distilled water. One tablet was placed in each of the six tubes of the apparatus containing distilled water. A disk was added to each tube. The time required for the complete disintegration of the tablet until no mass remaining in the tube was measured. The disintegration time of three tablets in a single batch was determined, and the mean value and standard deviation was calculated ${ }^{25}$.

\section{Modelling and Optimisation}

Design space can be described in terms of ranges of material attributes and process parameters, or through more complex mathematical relationships. It is generally determined through statistically designed experiment such as Design 
of Experiment (DoE). This enables maximum information with minimum experimental trials. Design space is only for $\mathrm{CPP}$ or critical material attributes that has direct impact to product CQA. It can be established for each unit operation or spans a few unit operations or the entire process ${ }^{26}$.

Experimental study data performed to create design space were evaluated with ANN and GEP modules in INForm program.

\section{Software Tools}

In this study, INForm V.5 ANN and INForm V.5 GEP (Intelligensys Ltd., UK) programs were used to develop predictive models and optimizes these models ${ }^{27}$. Whereas the task of establishing a central model is undertaken by the neural network element, genetic algorithms embedded in the software are used for optimization ${ }^{28}$. The Gene Expression Programming was used as an alternative to ANN for generating models to describe the linkages between the input and output parameters.

In our study, disintegrant type and amount and compression pressure were considered the inputs, and hardness, friability, wetting time, water absorption ratio and disintegration time were the outputs.

\section{Training Software Tools Parameters}

CPP and CMAs defined as variable factors and ANN and GEP modelling executed in INForm program by using the CQA results of the trials performed with these variable factors. Experimental data were analysed with the GEP and ANN to determine how to identify the optimum properties to achieve the optimum desired properties of the product formulation and/or treatment variables. In the programs, disintegrant type, disintegrant amount, Avicel ${ }^{\circledR}$ amount and compression pressure were considered the inputs; hardness, friability, wetting time, water absorption ratio and disintegration time were considered the outputs. Twelve formulations were used for model training. The test data selection was made using the "Smart Selection" method. The criterion for judging the models, fitness type was selected as Mean Square Error (MSE).

Because the training parameters influence the structure of the neural networks during the training process, the parameters in INForm V.5 was manipulated to optimize the predictability of the trained networks ${ }^{10}$. After trying various parameters, it was found that the parameters suggested in the ANN and GEP were suitable $^{29}$. The ANN program study conditions are given in Table 8 and GEP program study conditions are given in Table 9. To validate the predictability of trained models, the nonlinear coefficient of determination was computed against the validation data set. 
Table 8: INForm ANN study conditions for ODTs.

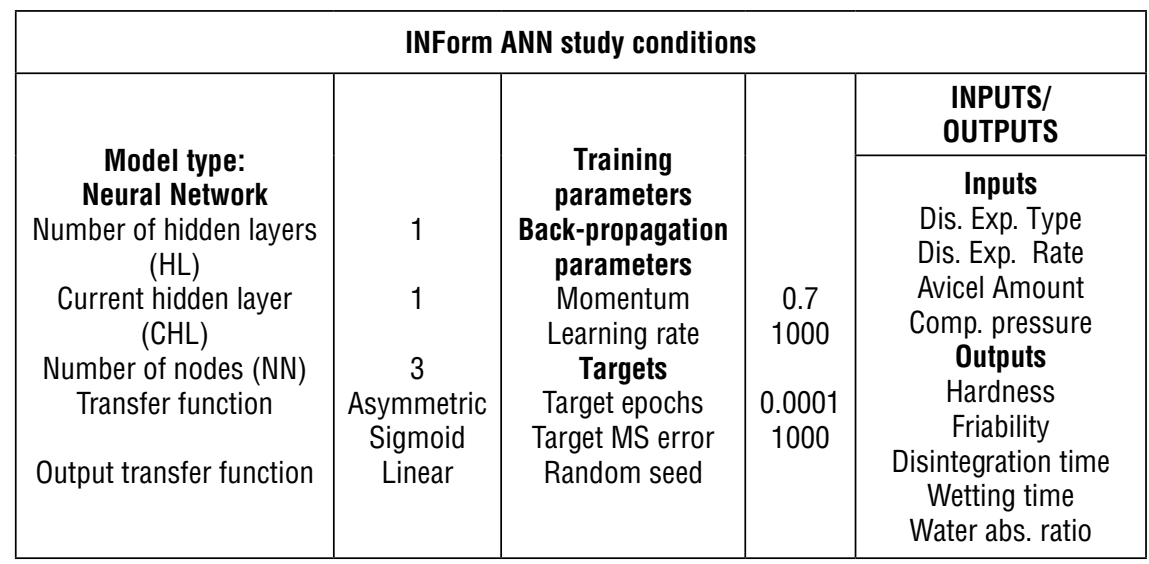

Table 9: INForm GEP study conditions for ODTs.

\begin{tabular}{|c|c|c|c|c|}
\hline \multicolumn{5}{|c|}{ INForm GEP study conditions } \\
\hline \multicolumn{2}{|c|}{$\begin{array}{l}\text { Model type: } \\
\text { Gene expression }\end{array}$} & \multicolumn{2}{|c|}{$\begin{array}{c}\text { Fitness type: } \\
\text { Mean Squared Error (MSE) }\end{array}$} & INPUTS/OUTPUTS \\
\hline $\begin{array}{l}\text { No. of populations } \\
\text { Population size } \\
\text { No. of generations } \\
\text { Headlength } \\
\text { Number of genes }\end{array}$ & $\begin{array}{c}10 \\
1000 \\
200 \\
7 \\
3\end{array}$ & $\begin{array}{l}\text { Node weighting factor } \\
\text { Minimum operator } \\
\text { nodes }\end{array}$ & $\begin{array}{c}0.5 \\
3\end{array}$ & $\begin{array}{c}\text { Inputs } \\
\text { Dis. Exp. Type } \\
\text { Dis. Exp. Rate } \\
\text { Avicel Amount } \\
\text { Compression pressure } \\
\text { Outputs } \\
\text { Hardness } \\
\text { Friability } \\
\text { Disintegration time } \\
\text { Wetting time } \\
\text { Water absorption }\end{array}$ \\
\hline
\end{tabular}

\section{Optimisation}

After the training was completed, ANN and GEP recommended a set of conditions (formulation) at which the optimum levels for the quality attributes could be achieved.

Optimisation of ODTs was performed in this study using the INForm V.5 ANN and GEP. When the INForm ANN and GEP model were trained, the model was optimized with target values based on pharmacopeial and in-house specifications. Then, to find the formulation with the closest match to the optimised formulation, the best match feature of the program was used.

During optimization stage, each property weight value was specified as 10 to evaluate the importance of each critical parameter on a scale of o to 10, with 10 being the most important. 
Optimisation parameters are:

Number of Populations: 1

Population Size: 100

Number of Iterations: 100

Mutation SD: 0.1

Random Seed: 1

\section{RESULTS AND DISCUSSION}

\section{Evaluation of Alfuzosin Hydrochloride Orally Dispersible Tablets}

\section{-Evaluation of blends before compression}

Results that belonged to the pre-compressing tests required for determination of flow properties such as bulk density, tapped density, Carr's (Compressibility) index and Hausner ratio of powder blends of ODT formulations are given in Table 10 .

Table 10: Flow characteristics of powder blends of ODT formulations.

\begin{tabular}{|c|c|c|c|c|c|c|c|c|c|}
\hline \multirow[b]{2}{*}{ Parameter } & \multicolumn{9}{|c|}{ Powder Blend } \\
\hline & 움 & $\underset{\text { 돈 }}{\stackrel{\sim}{\sim}}$ & $\underset{\text { 푼 }}{\stackrel{\sim}{\leftarrow}}$ & $\underset{⿱ 乛}{\frac{m}{4}}$ & 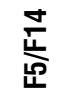 & 占 & $\underset{\frac{1}{\pi}}{\stackrel{0}{\pi}}$ & 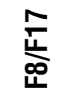 & $\underset{⿱ 亠 䒑}{\stackrel{\infty}{0}}$ \\
\hline Bulk density $(\mathrm{g} / \mathrm{mL})$ & 0.42 & 0.43 & 0.52 & 0.53 & 0.51 & 0.50 & 0.51 & 0.50 & 0.55 \\
\hline Tapped density $(\mathrm{g} / \mathrm{mL})$ & 0.57 & 0.62 & 0.7 & 0.73 & 0.7 & 0.65 & 0.72 & 0.67 & 0.75 \\
\hline Hausner ratio & 1.36 & 1.44 & 1.35 & 1.38 & 1.37 & 1.30 & 1.41 & 1.34 & 1.36 \\
\hline Carr's index & 26 & 31 & 26 & 27 & 27 & 23 & 29 & 25 & 27 \\
\hline
\end{tabular}

-Post compression evaluations

Results of the test applied to the tablets prepared are given in the Table 11. 
Table 11: The characteristics of ODT tablets prepared.

\begin{tabular}{|c|c|c|c|c|c|c|c|c|c|}
\hline \multirow{3}{*}{ 突 } & \multicolumn{3}{|c|}{$\begin{array}{l}\mathscr{y} \\
\text { 흘 } \\
\text { 혼 }\end{array}$} & \multirow{3}{*}{ 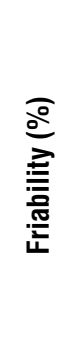 } & \multirow{3}{*}{ 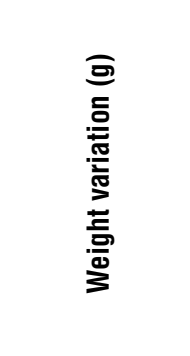 } & \multirow{2}{*}{\multicolumn{2}{|c|}{ 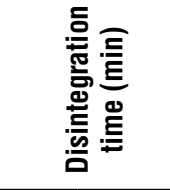 }} & \multirow{3}{*}{ 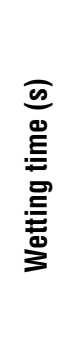 } & \multirow{3}{*}{ 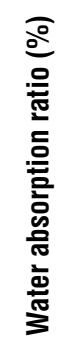 } \\
\hline & \multirow{2}{*}{ 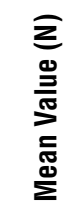 } & \multirow[b]{2}{*}{$\begin{array}{l}\text { II } \\
\text { क }\end{array}$} & \multirow[b]{2}{*}{ 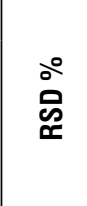 } & & & & & & \\
\hline & & & & & & 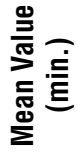 & $\begin{array}{l}\text { I1 } \\
\text { 品 }\end{array}$ & & \\
\hline $\mathrm{F} 1$ & 10.8 & 0.46 & 4.29 & 0.15 & $0.2001 \pm 0.001$ & 1.02 & 0.08 & 0.32 & 55.5 \\
\hline F2 & 11.7 & 0.51 & 4.32 & 0.19 & $0.1993 \pm 0.0016$ & 1.20 & 0.03 & 0.27 & 54.6 \\
\hline F3 & 8.02 & 1.01 & 12.53 & 0.55 & $0.1991 \pm 0.0009$ & 0.43 & 0.03 & 0.17 & 47.7 \\
\hline F4 & 9.82 & 0.82 & 8.37 & 0.41 & $0.2005 \pm 0.0011$ & 0.30 & 0.02 & 0.35 & 59.0 \\
\hline F5 & 8.7 & 0.25 & 2.87 & 0.37 & $0.2017 \pm 0.0011$ & 0.22 & 0.03 & 0.18 & 56.0 \\
\hline F6 & 8.9 & 0.1 & 1.08 & 0.55 & $0.2016 \pm 0.0012$ & 0.34 & 0.04 & 0.28 & 57.8 \\
\hline F7 & 16.5 & 1.36 & 8.24 & 0.12 & $0.1995 \pm 0.0011$ & 4.02 & 0.12 & 0.58 & 24.7 \\
\hline F8 & 15.5 & 0.45 & 2.91 & 0.16 & $0.2016 \pm 0.0016$ & 1.52 & 0.05 & 0.41 & 45.0 \\
\hline F9 & 14.58 & 0.22 & 1.49 & 0.21 & $0.2019 \pm 0.0009$ & 1.25 & 0.10 & 0.44 & 40.4 \\
\hline F10 & 17.95 & 0.93 & 5.18 & 0.34 & $0.2009 \pm 0.0012$ & 3.05 & 0.20 & 1.10 & 41.6 \\
\hline F11 & 16.42 & 0.81 & 4.92 & 0.31 & $0.2013 \pm 0.0015$ & 1.50 & 0.09 & 0.49 & 38.1 \\
\hline F12 & 16.9 & 1.03 & 6.09 & 0.40 & $0.2012 \pm 0.0014$ & 3.07 & 0.08 & 1.10 & 40.0 \\
\hline
\end{tabular}

\section{Optimisation with GEP and ANN Programs}

Models having been derived based on the ANOVA test results of the program were tested (See Table 12 and 13).

Table 12: The $R^{2}$ values calculated between ODTs included alfuzosin hydrochloride and anticipated values.

\begin{tabular}{|c|c|}
\hline \multicolumn{2}{|c|}{ INForm ANN - ODT Attributes / $\mathbf{R}^{\mathbf{2}}$ values } \\
\hline Outputs & $\mathbf{R}^{\mathbf{2}}$ \\
\hline Hardness (N) & 96.32 \\
\hline Friability (\%) & 97.51 \\
\hline Wetting time (s) & 91.65 \\
\hline Water absorption ratio (\%) & 97.38 \\
\hline Disintegration (s) & 96.92 \\
\hline Dissolution (\%) & 98.19 \\
\hline
\end{tabular}


Table 13: The $\mathrm{R}^{2}$ values calculated between ODTs included Alfuzosin hydrochloride and anticipated values.

\begin{tabular}{|c|c|}
\hline \multicolumn{2}{|c|}{ INForm GEP - ODT Attributes / $\mathbf{R}^{2}$ values } \\
\hline Outputs & $\mathbf{R}^{\mathbf{2}}$ \\
\hline Hardness (N) & 0,97 \\
\hline Friability (\%) & 0,98 \\
\hline Wetting time (s) & 0,99 \\
\hline Water absorption capacity (\%) & 0,92 \\
\hline Disintegration (s) & 0,97 \\
\hline Dissolution (\%) & 0,98 \\
\hline
\end{tabular}

ANN model gave information about which formulation is similar to the optimised formulation. Formulation 2 has the highest similarity to the optimised formulation at the rate of $60.01 \%$ (Table 14 ).

Table 14: The comparison of optimised Formulation and Formulation 2, the best match formulations according to the ANN model.

\begin{tabular}{|c|c|c|}
\hline & Optimised Formulation & Formulation 2 \\
\hline Superdisintegrant type & Ludiflash $®$ & Ludiflash ${ }^{\circledR}$ \\
\hline Superdisintegrant (\%) & 30.00 & 60.00 \\
\hline Avicel $^{\circledR}$ amount (mg) & 35.00 & 75.00 \\
\hline Compression pressure (psi) & 604.67 & 500.00 \\
\hline Hardness (N) & 11.13 & 11.70 \\
\hline Friability (\%) & 0.16 & 0.19 \\
\hline Wetting time (s) & 27.19 & 27.00 \\
\hline Water absorption ratio (\%) & 44.40 & 54.60 \\
\hline Disintegration (s) & 48.78 & 80.00 \\
\hline Dissolution (\%) & 74.77 & 49.57 \\
\hline
\end{tabular}

GEP model gave information about which formulation is similar to the optimised formulation. Formulation 3 has the highest similarity to the optimised formulation at the rate $89.64 \%$ (Table 15 ). 
Table 15: The comparison of optimised formula and Formulation 3, the best match formulations according to the GEP model.

\begin{tabular}{|c|c|c|}
\hline & Optimised Formulation & Formulation 3 \\
\hline Disintegrant type & Ludiflash ${ }^{\circledR}$ & Ludiflash $\AA$ \\
\hline Disintegrant amount (\%) & 69.36 & 80.00 \\
\hline Avicel $^{\circledR}$ amount (mg) & 35.00 & 35.00 \\
\hline Compression pressure (psi) & 547.00 & 500.00 \\
\hline Hardness (N) & 9.45 & 8.20 \\
\hline Friability (\%) & 0.34 & 0.55 \\
\hline Wetting time (s) & 21.91 & 17.00 \\
\hline Water absorption ratio (\%) & 48.62 & 47.70 \\
\hline Disintegration (s) & 42.46 & 43.00 \\
\hline Dissolution (\%) & 84.87 & 93.97 \\
\hline
\end{tabular}

With respect to the FMEA result and prior knowledge and experiences, taste, friability, hardness, disintegration time, wetting time and water absorption ratio were classified as CQAs, blending time and rate, sieve size and compression pressure were classified as CPPs. Disintegrant type (Ludiflash $®$ or combination of mannitol and sodium starch glycolate), disintegrant \% rate (30\% - 80\%) determined as CMAs. Whereas certain risk scores state that the appearance were not considered CQAs.

A total number of nine formulations were prepared and their powder blend characteristics were evaluated. For the flow characteristic of a powder mixture to be considered good, the Hausner ratio should be less than $1.25^{20}$. As shown in Table 10, the Hausner ratio for all the formulations was greater than 1.25, that's why the flow properties were considered as not so good. According to results formulations that were prepared had bed compressibility. In order to decide which formulations could be eliminated, formulations (Table 7) were compressed at 500 or 1000 psi and disintegration time was evaluated.

The disintegration time varied depending on the formulation components and the compression force, although all the formulations except F7, F10 and F12 complied with the European Pharmacopoeia limits ${ }^{25}$. The hardness values and compression forces of tablet formulation were directly proportional, as expected and F7, F10 and F12 formulations having the highest hardness value and the longest disintegration time. The friability values of tablet formulations were below $1 \%$.

All the tablets from each formulation passed weight variation test, as the \% weight variation was within the pharmacopoeia limits of $\pm 7.5 \%$ of the weight. The weight variation in all the prepared formulations was found to be $201 \pm 0.9$ 
and $199 \pm 0.9 \mathrm{mg}$, which was in pharmacopoeia limits ${ }^{31}$.

According to analyses conducted on tablets, experimental data was formed then evaluated via software uses artificial intelligence to perform mathematical modelling and optimization studies.

Based on the evaluation of the ANN data, an ODT formulation was recommended. The suggested "optimised formulation" contained $2.5 \mathrm{mg}$ alfuzosin hydrochloride, $30 \%$ Ludiflash $®$, and $35 \mathrm{mg}$ Avicel ${ }^{\circledR}$ and with a compression force of 605 psi. The program also provided "outputs" for the formula that it suggested. Accordingly, the predicted formulation properties of the optimised formula were $48.7 \mathrm{~s}$ for disintegration time, $11.1 \mathrm{~N}$ for hardness, $27 \mathrm{~s}$ for wetting time, $44 \%$ for water absorption ratio and $0.16 \%$ for friability.

The ANN model also provides us information about which formulation best fit the optimized formula. F2 was found to be the most similar to the optimized formula with a $60 \%$ similarity by the ANN model.

Based on the evaluation of the GEP data, an ODT formulation was recommended. The suggested "optimised formulation" contained $2.5 \mathrm{mg}$ alfuzosin hydrochloride, 69\% Ludiflash ${ }^{\circledR}$, and 35 mg Avicel ${ }^{\circledR}$ with a compression force of $547 \mathrm{psi}$. The program also provided "outputs" for the formula that it suggested. Accordingly, the predicted formulation properties of the optimised formula were $42.4 \mathrm{~S}$ for disintegration time, $9.45 \mathrm{~N}$ for hardness, $21.9 \mathrm{~s}$ for wetting time, $48.6 \%$ water absorption ratio and $0.33 \%$ for friability.

The GEP model also provides us information about which formulation best fit the optimized formula. F3 was found to be the most similar to the optimized formula with an $89.6 \%$ similarity by the GEP model.

It has been shown that both models proffer using Ludiflash $囚$, which contains Crospovidon, a polymer used in other studies ${ }^{32,33}$ as disintegrant within the ODT formulations and found suitable, in the tablet formulation to better quality properties and using it even in low amounts like $30 \%$ of total tablet weight will provide sufficient effect to maintain convenient disintegrating time and other quality attributes.

Even though there are several studies ${ }^{33}, 34$ conducted to show the convenient of using co-processed disintegrant or different disintegrant polymer forms, in this study using Artificial Intelligence Modelling methods aided to develop formulation with a novel approach.

\section{CONCLUSION}

Through our study, multiple experiments with direct compressed alfuzosin hydrochloride ODT were evaluated in order to understand relationships between input attributes and outputs were obtained. 
In these experiments, data was acquired on how the formulas and processes inputs affect output variables. Evaluating experimental results via GEP and/or ANN modelling software show the multivariate and complex relations among all the variables that determined as critical before, at the same time. Formulation and process knowledge on how the critical parameters affect the quality attributes were increased. Also, these modelling studies helped to develop models based on the known data results to estimate the unknown results for the data sets by optimization ability.

\section{REFERENCES}

1. Zhang, L.; Mao, S. Application of Quality by Design in the Current Drug Development. AJPS. 2017. 12, 1-8.

2. Aksu, B.; Mesut, B. Quality by Design (QbD) for Pharmaceutical Area. J. Fac. Pharm. Istanbul. 2015. 45(2), 233-251.

3. Thoorens, G.; Krier, F.; Leclercq, B.; Carlin, B.; Evrard, B. Microcrystalline cellulose, a direct compression binder in a quality by design environment-A review. Int. J. Pharm. 2014. 473, 6472.

4. ICH Q9, International Conference on Harmonization of Technical Requirements for Registration of Pharmaceuticals for Human Use, 2005, Risk Management.

5. Bhatia, H.; Read, E.; Agarabi, C.; Brorson, K.; Lute, S.; Yoon, S. A design space exploration for control of Critical Quality Attributes of mAb. Int. J. Pharm. 2016. 512 (1), 242-252.

6. Lionberger, R.,A.; Lee, S.,L.; Lee, L.; Raw, A.; Yu, L., X. Quality by Design: Concepts for ANDAs. AAPS J. 2008. 1O(2), 268-276.

7. Shivhare, M.; McCreath, G. Practical Considerations for DoE Implementation in Quality by Design, BioProcess Int. 2010. 8, 22-30.

8. Tomba, E.; Facco, P.; Bezzo, F.; Barolo, M. Latent variable modelling to assist the implementation of Quality-by-Design paradigms in pharmaceutical development and manufacturing: A review. Int J Pharm. 2013. 457, 283-297.

9. ICH Q8, International Conference on Harmonization of Technical Requirements for Registration of Pharmaceuticals for Human Use, Pharmaceutical Development Guideline, 2009, Q8(R2).

10. Aksu, B.; Paradkar, A.; Matas, M.; Özer, Ö.; Güneri, T.; York, P. Quality by Design Approach: Application of Artificial Intelligence Techniques of Tablets Manufactured by Direct Compression. AAPS PharmSciTech. 2012. 13(4), 1138-1146.

11. Mesut, B.; Aksu, B.; Özsoy, Y. Design of Sustained Release Tablet Formulations of Alfuzosin HCl by means of Neuro-Fuzzy Logic. Lat. Am. J. Pharm. 2013. 32 (9), 1288-1297.

12. Landin, M.; Rowe, R.,C.; York, P. Establishing and Analyzing the Design Space in the Development of Direct Compression Formulations by Gene Expression Programming. Int $\mathrm{J}$ Pharm. 2012, 434 (1-2), 35-42.

13. Pahwa, R.; Gupta, N. Superdisintegrants In The Development Of Orally Disintegrating Tablets: a Review. IJPSR. 2011. 2(11), 2767-2780.

14. Velmurugan, S.; Vinushitha, S. Oral disintegrating tablets: An overview. IJCPS, 2010. 1(2), 1- 12.

15. Aksu, B.; Yegen, G.; Purisa, S.; Cevher, E.; Ozsoy, Y. Optimisation of ondansetron orally disintegrating tablets using artificial neural networks. Trop J Pharm Res, 2015. 13(9), 1374 -1383. 
16. Sweetman, S.C. Martindale: The complete drug reference, $33^{\text {rd }}$ Ed. Pharmaceutical Press, London. 2002.

17. Leela, M.,K.; Ramana, G. Digpati R. Formulation and Evaluation of Oral disintegrated tablets of Alfuzosin Hydrochloride using super-disintegrants. JAPS. 2011. 1(9), 161-165.

18. McCurdy, V. Quality by Design, In The Process Understanding: For Scale-Up and Manufacture of Active Ingredients, $1^{\text {st }} \mathrm{Ed}$.; Houson I., Wiley-VCH, 2011: pp 1-16.

19. Franceschini, F.; Galetto, M. A New Approach for Evaluation of Risk Priorities of Failure Modes in FMEA. Int J Prod Res. 2001. 39(13), 2991-3002.

20. USP 35. General Information / <1174> Powder Flow

21. EP 7 2.9.34. Bulk Density And Tapped Density of Powders

22. USP 35. General Information / <1216> Tablet Friability.

23. Brniak, W.; Jachowicz, R.; Pelka, P. The Practical Approach to the Evaluation of Methods Used to Determine the Disintegration Time of Orally Disintegrating Tablets (ODTs). SPJ. 2015. 23(4), 437-443.

24. Sharma, R.; Kamboj, S.; Singh, G.; Rana, V. Development of Aprepitant Loaded Orally Disintegrating Films for Enhanced Pharmacokinetic Performance. Eur J Pharm Sci. 2016. 84, 55-60.

25. European Pharmacopoeia 5.o. Pharmaceutical technical procedures: 2.9.1. Disintegration of Tablets and Capsules. 01/2005:20901

26. Annex C Guidance for Quality by Design as an Alternative Approach to process Validation. http://www.hsa.gov.sg/content/dam/HSA/HPRG/Western_Medicine/Overview_Framework_ Policies/Guidelines_on_Drug_Registration/ANNEX\%20C.pdf .Accessed on 05.01.2017.

27. Aksu, B.; De Matas, M.; Cevher, E.; Özsoy, Y.; Güneri, T.; York, P. Quality by Design Approach for Tablet Formulations Containing Spray Coated Ramipril by Using Artificial Intelligence Techniques. Int J Drug Del. 2012. 4(1), 59-69.

28. Aksu, B.; Aydoğan, M.; Kanik, B.; Aksoy, E. A Flexible Regulatory Approach for Different Raw Materials Suppliers Using QbD Principles. RJPBCS. 2013. 4(4), 358-372.

29. Aksu, B.; Paradkar, A.; De Matas, M.; Özer, Ö.; Güneri, T.; York, P. A Quality by Design Approach Using Artificial Intelligence Techniques to Control the Critical Quality Attributes of Ramipril Tablets Manufactured by Wet Granulation. Pharm Dev Technol. 2013. 18(1), 236-245.

30. USP 35. General Information / <905> Uniformity Of Dosage

31. Stoltenberg, I.; Breitkreutz, J. Orally Disintegrating Mini-Tablets (ODMTs) - A Novel Solid Oral Dosage Form for Paediatric Use. Eur. J. Pharm. Biopharm. 2011. 78(3), 462-469.

32. Amelian, A.; Winnicka, K. Effect of the Type of Disintegrant on the Characteristics of Orally Disintegrating Tablets Manufactured Using New Ready-to-Use Excipients (Ludiflash $₫$ or Parteck $($ ) by Direct Compression Method. AJPP. 2012. 6(31), 2359-2367.

33. Iwao, Y.; Tanaka, S.; Uchimoto, T.; Noguchi, S.; Itai, S. An Easy-to-Use Approach for Determining the Disintegration Ability of Disintegrants by Analysis of Available Surface Area. Int $J$ Pharm. 2013. 448(1), 1-8.

34. Katsuno, E.; Tahara, K.; Takeuchi, Y.; Takeuchi, H. Orally Disintegrating Tablets Prepared by a Co-Processed Mixture of Micronized Crospovidone and Mannitol Using a Ball Mill to Improve Compactibility and Tablet Stability. Powder Technol. 2013. 241, 60-66.

(Received 15 February 2017; accepted o8 March 2017) 